\title{
CORRELATION OF HTERT EXPRESSION WITH CERVICAL CYTOLOGICAL ABNORMALITIES AND HUMAN PAPILLOMAVIRUS INFECTION
}

\author{
Vjosa A. Zejnullahu' ${ }^{1}$, Valon A. Zejnullahu ${ }^{1}$, Slavica Josifovska ${ }^{2}$, \\ Nikola Vukovik ${ }^{2}$, Kiril Pakovskiं ${ }^{2}$, Sasho Panov ${ }^{2}$ \\ ${ }^{1}$ Department of Obstetrics and Gynecology, University Clinical Center of Kosovo, Pristina, Kosovo \\ ${ }^{2}$ Department of Molecular Biology, Genetics and Microbiology, Institute of Biology, Faculty of Natural Sciences \\ and Mathematics, Ss. Cyril and Methodius University, Skopje, Republic of Macedonia
}

Corresponding author: Sasho Panov, PhD. Department of Molecular Biology, Genetics and Microbiology, Institute of Biology, Faculty of Natural Sciences and Mathematics, Ss. Cyril and Methodius University, Arhimedova 3, 1000 Skopje, Macedonia. Phone: +38970248790. E-mail: sasho@mt.net.mk

\begin{abstract}
Telomerase Reverse Transcriptase (TERT) is the main catalytic sub-unit of telomerase, a reverse transcriptase enzyme. Telomerase expression is regulated at many levels, with numerous studies suggesting that up-regulation of human TERT gene (hTERT) at transcriptional level results in immortal cell phenotype associated with cancer. The aim of this study is to determine the correlation between hTERT expression and different cervical precursor lesions, as well as with cervical cancer in patients with confirmed Human papillomavirus (HPV) infection.

The study included molecular analyzes on cervical samples from 214 women and matched Papanicolaou (Pap) test results. HPV detection and genotyping was performed by polymerase chain reaction (PCR) and genotyping. Quantitative real-time PCR (qRT-PCR) was performed using TaqMan probes and were calculated relative to the reference gene.

Results showed significantly increased hTERT mRNA expression levels in high-grade and low-grade lesions compared to normal control samples $(\mathrm{p}<0.01)$ associated with 6.31 fold higher risk for developing ASC-US and 9.20 for LSIL. Strong correlation between HPV infection and hTERT expression in the high-grade lesions and cervical cancer was also observed. hTERT relative expression values showed $98 \%$ specificity and $100 \%$ sensitivity as indicator of cervical lesions particularly for the ACS-H, HSIL and cervical cancer. In conclusion, hTERT expression correlate with the cytological grade of the cervical lesions and HPV infection and has a potential to be used as a diagnostic and prognostic marker.
\end{abstract}

Keywords: Telomerase Reverse Transcriptase, gene expression, cervical cancer, Human papillomavirus

\section{INTRODUCTION}

Cervical cancer is caused by a dynamic biological process that causes transformation from normal epithelium through cervical precursor lesions and ends with malignant transformation and invasion.

Well organized screening programs in developed countries decreased the incidence and mortality rate of patients with cervical cancer. However, more than $80 \%$ of women in developing countries are diagnosed with cervical cancer, thus being the leading cause of cancer-related death in low-resource countries and third most common cancer in women worldwide [1, 2]. According to the 2015 annual report of the National Institute of Public Health of Kosovo, 68 new cases of cervical cancer were diagnosed in Kosovo in 2015.

Disease progression is through different phases of cervical precursor lesions [3]. The persistent chronic 
infection with high-risk HPV types, high virus load or infection with several oncogenic types play a crucial role in progression [4, 5]. High-risk HPV types interfere with cell cycle through inactivation of $\mathrm{p} 53$ gene product via E6/E6AP complex and E7-mediated inactivation of $\mathrm{Rb}$ protein [6]. Malignant transformation of cells infected with high-risk HPV can be triggered by transcriptional up-regulation of the hTERT by E6/E7 oncoproteins causing high replicative potential of the cells and immortalization $[7,8,9]$.

Cell immortalization due to maintenance of the length of telomeres is caused by alternative telomere lengthening (ALT) or activation of telomerase [10]. Telomerase is a ribonucleoprotein enzyme consisting of enzymatic component Telomerase Reverse Transcriptase (hTERT), RNA template component (TR) and telomerase subunits Dyskerin (DKC), Reptin and Pontin [11-14]. Telomerase prevents the cells to enter mortality by resolving the end-replication problem with adding hexameric TTAGGG sequences at the chromosome ends [15]. Increased telomerase activity was demonstrated in up to $80-90 \%$ of human cancers including breast, lung, gastric, colorectal, bladder and cervical cancer, as well as in precancerous lesions [10].

Normal cells show no tolow detectable telomerase activity due to the transcriptional repression of the hTERT $[16,17]$. Telomerase activity was detected in normal mucosa of colon and small intestines $[18,19,20]$. hTERT was detected immunohistochemically in suprabasal layers of normal cervix [21]. Depending on the phase of the menstrual cycle, endometrial cells show high telomerase activity [22-26].

Detection of the telomerase activity by TRAP assay is limited by difficulty to distinguish malignant cells from highly proliferative normal cells like germ cells, stem cells, activated lymphocytes and some epithelial cells. This limitation is not present in quantitative measurement of transcriptional activity of hTERT by qRT-PCR although its role as early diagnostic and prognostic marker still remains obscure despite intensive research [10].

The aim of this study is to investigate the correlation between hTERT expression levels with different cytological sub-groups and HPV infection in population of women form Pristina, Kosovo.

\section{MATERIALS AND METHODS}

Study subjects and data collection

This prospective case-control study was conducted in the Outpatient Clinic for Obstetrics and Gynecology at the University Clinical Center in Pristina, Kosovo and the Department of Molecular Biology, Genetics and Microbiology, Ss. Cyril and Methodius University, Skopje, Macedonia, between September, 2015 and September, 2016. After meeting the inclusion and exclusion criteria, total of 214 women who were screened for cervical cancer were included in the study. Eligible subjects were of age 20-65, with normal or abnormal cytological results according to the Bethesda 2001 guidelines, sexually active or previous sexually active and negative or positive HPV status with determined genotype including mixed infections. Women with a history of hysterectomy, cold-knife conisation or loop electrosurgical excision procedure (LEEP) within 12 months prior, as well as pregnant and postpartum women were excluded from the study. Other known malignancy, not determined HPV infection status or inconclusive PAP cytology, were also exclusion criteria.

Informed consent was taken from all participants. The study protocol was approved by the Ethical Review Committee at the University Clinical Center of Kosovo with reference number 1/1292/2016. Specially designed anonymous questionnaire for demographic and clinically pathological parameters including the age, parity, abortions, smoking history, hormonal contraception use and other co-morbidities was filled out for each patient.

Two cervical samples from endo and exocervix were obtained from each subject. First cervical smear by cytobrush was used for cytological examination and the second one collected with swab and kept at $-20^{\circ} \mathrm{C}$ until further processing was for detection and genotyping of HPV DNA and determination of hTERT expression levels according to the research protocol.

Cytological examination conducted for all subjects was performed by conventional Pap testing interpreted according to the Bethesda 2001 guidelines.

\section{HPV detection and genotyping}

DNA was isolated from all 214 samples with chloroform/phenol protocol and identification of the L1 region sequence of HPV genome was conducted by PCR with MY09/MY11 primers on a PCR 9700 thermocycler (Applied Biosystems), following by genotyping using restriction fragment length polymorphism analysis, as described elsewhere [27].

Quantitative Real-Time PCR for telomerase gene expression

Quantitative expression of the hTERT gene was determined by two-step reverse transcription of 
the RNA samples and Real-Time PCR amplification using fluorescent TaqMan probes on OneStep RealTime PCR System (Applied Biosystems). Total RNA was isolated from swab-collected cervical cells using TRI-reagent and cDNA was synthesized by reverse transcription using High-Capacity cDNA Reverse Transcription Kits (Thermo-Fisher) according to the manufacturer's instructions. The oligonucleotide primers and TaqMan probes used were as follows: hTERT gene, forward primer 5'-GCA TTG GAA TCA GAC AGC AC-3', reverse primer 5'-CCA CGA CGT AGT CCA TGT TC-3', probe 5'FAMCGC CCT GCT GAC GTC CAG AC-NFQ3'; reference GAPDH gene, forward primer 5'-ATG GGT GTG AAC CAT GAG AA-3', reverse primer 5'-GTG CTA AGC AGT TGG TGG TG-3', probe 5'FAM-CCT CAA GAT CAT CAG CAA TGC CTC C-NFQ 3'. Primers and probes sequences, as well as amplification conditions were used as described elsewhere [28]. Expression levels of hTERT were calculated by the method of Livak, 2001, relative to the expression of a housekeeping gene GAPDH [29].

\section{Statistical analysis}

Two-sided Mann Whitney test was used to compare hTERT expression among cytological groups. The association between the binary normal and over-expression of hTERT with cytological groups was calculated by the Fisher exact test and multivariate analysis of variance (MANOVA). The correlation between the presence of HPV infection and hTERT expression was estimated by Logistic regression analysis.

\section{RESULTS}

Cytology testing of the 214 patients resulted in $100(46.73 \%)$ patients with normal cytology results, further used as control group, and 114 (53.27\%) patients with cytological abnormalities that were further stratified according to the Bethesda-based cytology classification. The samples with cytological abnormalities included 45 cases $(21.03 \%)$ with atypical squamous cells of undetermined significance (ASC-US), 37 cases (17.29\%) with low-grade squamous intraepithelial lesions (LSIL), 7 cases (3.27\%) with atypical squamous cells-cannot exclude HSIL (ASC-H), 15 cases (7.01\%) with high-grade squamous intraepithelial lesions (HSIL) and 10 cases (4.67\%) with Cervical carcinoma.

The main statistical parameters regarding the relative expression levels of hTERT gene in the samples from 6 cytological groups, as well as in all patients, are presented in the Table 1.

Table 1. Basic statistical parameters of hTERT expression values in patients with different cytology

\begin{tabular}{|c|c|c|c|c|c|c|c|}
\hline 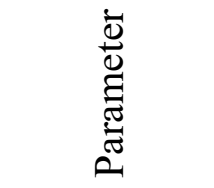 & $\begin{array}{l}\overline{\widetilde{Z}} \\
\text { Z̃ } \\
\text { Z }\end{array}$ & 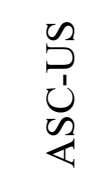 & $\vec{\sim}$ & $\begin{array}{l}\frac{\pi}{1} \\
\text { Un } \\
\text { \& }\end{array}$ & $\begin{array}{l}\exists \\
\stackrel{\Xi}{I}\end{array}$ & 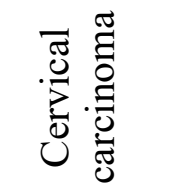 & 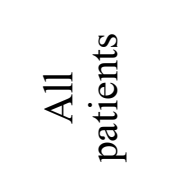 \\
\hline $\mathrm{n}$ & 100 & 45 & 37 & 7 & 15 & 10 & 214 \\
\hline$\%$ & 46.73 & 21.03 & 17.29 & 3.27 & 7.01 & 4.67 & 100.00 \\
\hline Minimum & 0.15 & 0.64 & 0.80 & 74.28 & 38.20 & 56.62 & 0.15 \\
\hline Maximum & 3.17 & 17.86 & 13.25 & 489.28 & 704.46 & 952.88 & 952.88 \\
\hline 1st Quartile & 0.56 & 2.34 & 2.31 & 142.47 & 83.49 & 74.62 & 1.00 \\
\hline Median & 1.01 & 3.61 & 5.32 & 206.41 & 131.50 & 107.36 & 2.31 \\
\hline 3rd Quartile & 1.98 & 5.25 & 7.86 & 253.24 & 368.55 & 157.19 & 5.80 \\
\hline Mean & 1.27 & 4.19 & 5.56 & 223.06 & 221.34 & 199.67 & 34.58 \\
\hline $\begin{array}{c}\text { Variance } \\
(\mathrm{n}-1) \\
\end{array}$ & 0.65 & 11.58 & 11.97 & 18108.58 & 36453.93 & 73548.38 & 11783.89 \\
\hline $\begin{array}{c}\text { Standard } \\
\text { deviation } \\
(\mathrm{n}-1)\end{array}$ & 0.81 & 3.40 & 3.46 & 134.57 & 190.93 & 271.20 & 108.55 \\
\hline
\end{tabular}


Two-sided Shapiro-Wilk test showed that hTERT expression values do not follow normal statistical distribution $(\mathrm{W}=0.348 ; \mathrm{p}<0.0001)$, which was taken into account for further selection of statistical methods. There is an obvious increase in the mean hTERT gene expression levels from normal cytological group up to the cervical cancer group. Variations from the mean vales, as shown by the standard deviation, are also gradually increasing and reaching maximum in HSIL cytological group.

Statistical analysis using two-sided MannWhitney test revealed that hTERT expression levels differ significantly in each of the 5 patient groups with cytological abnormalities versus the reference normal group (ref.) $(\mathrm{p}<0.01)$. Difference between all 6 cytological groups was also observed when the KruskalWallis test was used. In order to compare the hTERT expression with relevant patient's parameters, a cut-off value was arbitrarily set for hTERT overexpression equal to mean levels in normal cells plus twice the standard deviation.

The frequency distribution of patients with overexpressed hTERT gene calculated by cut-off value is presented in the Table 2.

The difference between the hTERT normal expression levels and overexpression in the normal reference group (ref.) and each of the 5 groups with cytological abnormalities was highly significant $(\mathrm{p}<0.01)$, as well as among all 6 cytological groups. Furthermore, calculations indicate that the patients with overexpressed hTERT gene has 6.31 and 9.20 folds higher risk for developing ASC-US and LSIL lesions, respectively, than the patients with normal expression, regarding normal cytology.

The correlation between hTERT expression and cytological groups was confirmed by general MANOVA (multivariate analysis of variance) by Rao's approximation of the Wilks' test $(\mathrm{p}<0.0001)$.

The association of HPV infection and overexpression regarding the cytological groups was presented in Table 3.

Correlation between the hTERT expression levels and HPV infection regarding the 6 cytological groups was determined by Logistic regression analysis. Binary variable of absence or presence of HPV infection versus quantitative variables for relative hTERT gene expression levels was used in this statistical test. The relationship was statistically highly significant, as estimated by Wald test (Chisquare $=8.483 ; p=0.004)$ and the likelihood ratio $(-2$ Log test) (Chi-square $=21.460 ;<0.0001)$. The area under the receiver operating characteristic (ROC) curve is 0.779 , indicating fair accuracy (data not shown).

The sensitivity and specificity of the hTERT gene relative expression values as a biomarker for cervical cancer and its precursor lesions is presented in the Table 4.

It is apparent that hTERT as biomarker test is most suitable for higher-grade cytological cervical lesions: ASC-H, HSIL and Cervical carcinoma.

Table 2. Differences in the hTERT expression levels between cytological groups

\begin{tabular}{|c|c|c|c|c|c|c|c|c|}
\hline \multirow[t]{2}{*}{ Group } & \multicolumn{2}{|c|}{$\begin{array}{c}\text { Normal } \\
\text { hTERT levels }\end{array}$} & \multicolumn{2}{|c|}{$\begin{array}{l}\text { hTERT over- } \\
\text { expression }\end{array}$} & \multicolumn{2}{|c|}{$\begin{array}{c}\text { Fisher's } \\
\text { exact test }\end{array}$} & \multicolumn{2}{|c|}{$\begin{array}{l}\text { Risk } \\
\text { ratio }\end{array}$} \\
\hline & $n$ & $\%$ & $\mathrm{n}$ & $\%$ & & 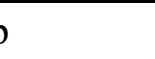 & RR & CI $(95 \%)$ \\
\hline Normal & 98 & 98.00 & 2 & 2.00 & ref. & & ref. & ref. \\
\hline ASC-US & 17 & 37.78 & 28 & 62.22 & $<0.0001$ & & 6.31 & $\begin{array}{l}4.03- \\
9.89 \\
\end{array}$ \\
\hline LSIL & 11 & 29.73 & 26 & 70.27 & $<0.0001$ & & 9.20 & $\begin{array}{l}5.21- \\
16.27 \\
\end{array}$ \\
\hline ASC-H & 0 & 0.00 & 7 & 100.00 & $<0.0001$ & & \# & $\#$ \\
\hline HSIL & 0 & 0.00 & 15 & 100.00 & $<0.0001$ & & $\#$ & $\#$ \\
\hline Cervical carcinoma & 0 & 0.00 & 10 & 100.00 & $<0.0001$ & & $\#$ & $\#$ \\
\hline All patients & 126 & 58.88 & 88 & 41.12 & & $<0.0001$ & & \\
\hline
\end{tabular}

\# could not be calculated due to the presence of zero values in the compared groups.

CI (95\%): confidence interval at 95\% 
Table 3. Distribution of HPV infection and hTERT overexpression regarding the cytological groups

\begin{tabular}{|l|c|c|c|c|c|c|c|c|c|c|}
\hline Group & \multicolumn{2}{|c|}{$\begin{array}{c}\text { HPV negativ } \\
\text { and normal } \\
\text { hTERT levels }\end{array}$} & $\begin{array}{c}\text { HPV } \\
\text { positive } \\
\text { and normal } \\
\text { hTERT } \\
\text { levels }\end{array}$ & $\begin{array}{c}\text { HPV negative } \\
\text { and hTERT } \\
\text { overex- } \\
\text { pres-sion }\end{array}$ & $\begin{array}{c}\text { HPV positive } \\
\text { and hTERT } \\
\text { overex- } \\
\text { pres-sion }\end{array}$ & \multicolumn{2}{|c|}{$\begin{array}{c}\text { Fisher's } \\
\text { exact test }\end{array}$} \\
\hline & $\mathrm{N}$ & $\%$ & $\mathrm{n}$ & $\%$ & $\mathrm{n}$ & $\%$ & $\mathrm{n}$ & $\%$ & $\mathrm{p}$ & $\mathrm{p}$ \\
\hline Normal & 79 & 79.00 & 19 & 19.00 & 2 & 2.00 & 0 & 0.00 & ref. & \\
\hline ASC-US & 7 & 15.56 & 10 & 22.22 & 10 & 22.22 & 18 & 40.00 & $<0.0001$ & \\
\hline LSIL & 1 & 2.70 & 10 & 27.03 & 4 & 10.81 & 22 & 59.46 & $<0.0001$ & \\
\hline ASC-H & 0 & 0.00 & 0 & 0.00 & 1 & 14.29 & 6 & 85.71 & 1.000 & \\
\hline HSIL & 0 & 0.00 & 0 & 0.00 & 1 & 6.67 & 14 & 93.33 & $<0.0001$ & \\
\hline $\begin{array}{l}\text { Cervical } \\
\text { carcinoma }\end{array}$ & 0 & 0.00 & 0 & 0.00 & 0 & 0.00 & 10 & 100.00 & 0.008 & \\
\hline All patients & 87 & 40.65 & 39 & 18.22 & 18 & 8.41 & 70 & 32.71 & & $<0.0001$ \\
\hline
\end{tabular}

Table 4. The sensitivity and specificity of the hTERT gene relative expression values as a biomarker for cervical cancer and its precursor lesions

\begin{tabular}{|l|c|l|l|l|}
\hline Group & $\begin{array}{l}\text { Normal hTERT } \\
\text { levels }\end{array}$ & hTERT overexpression & Sensitivity & Specificity \\
\hline Normal & 98 & 2 & ref. & ref. \\
\hline ASC-US & 17 & 28 & 62.22 & 98.00 \\
\hline LSIL & 11 & 26 & 70.27 & 98.00 \\
\hline ASC-H & 0 & 7 & 100.00 & 98.00 \\
\hline HSIL & 0 & 15 & 100.00 & 98.00 \\
\hline Cervical carcinoma & 0 & 10 & 100.00 & 98.00 \\
\hline $\begin{array}{l}\text { All groups of abnor- } \\
\text { mal cytology }\end{array}$ & 28 & 86 & 75.44 & 98.00 \\
\hline
\end{tabular}

\section{DISCUSSION}

Numerous studies indicate that the low sensitivity of a single Pap-test causes under- and over-treatment of the patients in clinical settings to be common. A better diagnostic and predictive marker of disease progression would provide a tool to reduce unnecessary invasive procedures.

Significantly increased levels of the hTERT in high-grade and low-grade lesions compared to the normal samples suggest that hTERT can be used as an early diagnostic and prognostic marker. Our results are comparable to previous studies in which hTERT expression relates to the severity of the disease [30-32].
Saretzki et al. found no correlation between the telomerase activity and severity of the lesion whereas Reesink-Peters et al. reported low expression of the hTERT component without differences between the CIN 0/I and CIN II/III groups [33,34]. Published studies on the subject reveal that hTERT expression and telomerase activity was reported in $91.3 \%, 96.5 \%$ and $100 \%$ of cervical cancer samples [35-37]. Increased hTERT expression was also seen in $55.0 \%$ of CIN II and $82.1 \%$ of CIN III diagnosed [38].

Duque et al., had similar results by TRAP assay regarding the telomerase activity in range from $75.4 \%$ in LSIL to $100 \%$ in HSIL, ASC-H and cervical cancer [37].

We observed a strong correlation between the hTERT normal expression and hTERT over- expression in all groups, compared to normal results, as well as 
between the groups with cytological abnormalities $(\mathrm{p}<0.01)$. The percentage of the hTERT over-expression calculated by cut-off value (mean levels in normal cells $+2 \mathrm{SD}$ ) in cytological samples was $62.22 \%$, and $70.27 \%$ in ASC-US, LSIL, respectively and $100 \%$ in ASC-H, HSIL and cervical cancer. Therefore, hTERT over-expression is highly predictive and can be used as complementary diagnostic tool for high-grade lesions and cervical cancer. Our results of hTERT being overexpressed in only $2 \%$ of normal samples suggest that it can be used as an accessory approach for confirmation of low-grade lesions. Similar results regarding the telomerase activity and hTERT expression in normal samples have been previously published [36, 38-39].

We also observed strong association between the hTERT expression and HPV infection in our patients. Previous studies are contradictory in regards of this association. Ault et al, reported no significant correlation between the HPV 16/18 detection and telomerase levels [40]. Branca et al. and Wang et al. noticed strong association between the high-risk HPV types and hTERT upregulation, leading to increased expression [30]. Kailash et al, determined strong association between the high-risk-HPV and telomerase activity [41]. In our study hTERT over- expression in HPV-negative cells was found in $22.22 \%, 10.81 \%$, $14.29 \%$ and $6.67 \%$ of ASC-US, LSIL, ASC-H and HSIL respectively, which could be explained by the presence of fraction of telomerase positive cells and non-dysplastic cells in the samples, or by alternative mechanisms of transcriptional regulation of hTERT instead of HPV-oncoprotein regulation in those samples $[42,43]$.

The detected hTERT over-expression in HPVpositive cells in $85.71 \%, 93.33 \%$ and $100 \%$ in ASC-H, HSIL and cervical cancer, respectively, indicates that there is a high correlation between hTERT overexpression and HPV infection particularly in highergrade lesions and cervical cancer. One of the most important mechanisms by which hTERT is upregulated independently of c-myc over-expression or p53 degradation is transcriptional upregulation by the E6/ E7 oncoproteins from high-risk HPV types. HPV-16 E6 oncoprotein was shown to activate telomerase expression in human keratinocytes and mammary cells in p53-independent mechanism [44]. High-risk HPVs interfere with cell cycle through inactivation of an important transcriptional regulator, p53 tumor suppressor gene product and the retinoblastoma protein $(\mathrm{Rb})$ together with other associated proteins like p107, p130 and p105 [45]. Oh et al, demonstrated that E6 induces hTERT expression by interaction with hTERT promoter proximal to the initiation codon [46]. Our results are in accordance with the findings that in highgrade lesions and cervical cancer deregulated E6/E7 expression with or without integration of the viral genome into the host chromosome and subsequent chromosomal instability are required for hTERT overexpression and telomerase activity [47, 48].

Regarding the detection of telomerase activity in the cytological samples compared to cervical biopsies, we found that exfoliative smear sampling is useful to determine hTERT expression and therefore telomerase activity. Thus, quantitative RT-PCR determination of hTERT expression in cytological samples may be useful in distinction of the high-grade lesions and progressive disease from the low-grade lesions. However, Gorham et al. demonstrated that exfoliated cells are not a reliable indicator for telomerase activity [25]. A study from Wang et al. showed similar results of detection of the telomerase activity in cytological samples and cervical biopsies [49]. The increased detection rate for highgrade lesions and cervical cancer in our study compared to other studies using TRAP assay is explained by the higher sensitivity of the hTERT RT-PCR method similar to a study from Snijders et al. [50].

Finally, our data indicate that the hTERT gene expression values could be used as a highly specific and sensitive markers for ASC-H, HSIL and cervical cancer ( $98 \%$ and $100 \%$, respectively). Similarly, Branca et al reported $90.0 \%$ specificity of hTERT expression for detection of cervical lesions, although with lower sensitivity (57.5\%), compared to our results [30]. Therefore, testing hTERT expression levels can supplement the cytological diagnosis, which has a low sensitivity and a high false negative rate, and can compensate for low specificity of the HPV testing.

The potential limitation of small sample size in the present study will be addressed by a future larger cohort study.

\section{CONCLUSION}

Our data confirm thathTERT expression occurs early in progression of the cervical precancerous lesions and correlates with disease severity and HPV infection. Consequently, determination of hTERT expression levels in cervical cells collected by Pap smear could potentially be used as a useful supplementary diagnostic and prognostic marker of the cervical disease in HPVinfected subjects. 


\section{REFERENCES}

1. Ferlay J, Soerjomataram I, Ervik M, et al. GLOBOCAN 2012 v1.1, Cancer Incidence and Mortality Worldwide: IARC CancerBase No. 11 [Internet]. Lyon, France: International Agency for Research on Cancer; 2013. Available at: http://globocan.iarc.fr, last accessed on 23/01/2017.

2. Ferlay J, Steliarova-Foucher E, Lortet-Tieulent J, et al. Cancer incidence and mortality patterns in Europe: estimates for 40 countries in 2012. Eur J Cancer. 2013; 49(6):1374-403.

3. Richart RM. Cervical intraepithelial neoplasia. Pathol Annu. 1973; 8:301-28.

4. Lorincz AT, Reid R, Jensen AB, et al. Human papillomavirus infection of the cervix; Relative risk associations of 15 common anogenital types. Obstet Gynecol. 1992;39(2):152.

5. Zuna RE, Wang SS, Schiffman M, et al. Comparison of human papillomavirus distribution in cytologic subgroups of low-grade squamous intraepithelial lesion. Cancer. 2006; 108(5):288-97. DOI: 10.1002/ cncr.22168.

6. Yim EK, Park JS. The role of HPV E6 and E7 oncoproteins in $\mathrm{HPV}$-associated cervical carcinogenesis. Cancer Res Treat. 2005; 37(6):319-24. DOI: 10.4143/ crt.2005.37.6.319.

7. Gewin L, Galloway DA. E box-dependent activation of telomerase by human papillomavirus type 16 E6 does not require induction of c-myc. J. Virol 2001. 75:7198201. DOI: 10.1128/JVI.75.15.7198-7201.2001.

8. Oh, ST, Kyo S, Laimins LA. Telomerase activation by human papillomavirus type 16 E6 protein: induction of human telomerase reverse transcriptase expression through Myc and GC-rich Sp1 binding sites. J Virol. 2001; 75:5559-66. DOI: 10.1128/JVI.75.12.55595566.2001 .

9. Veldman T, Horikawa I, Barrett JC, et al. Transcriptional activation of the telomerase hTERT gene by human papillomavirus type 16 E6 oncoprotein. J Virol. 2001. 75:4467-72. DOI: 10.1128/JVI.75.9.4467-4472.2001.

10. Chen $\mathrm{CH}$, Chen RJ. Prevalence of telomerase activity in human cancer. J Formos Med Assoc. 2011; 110(5):27589. DOI:10.1016/S0929-6646(11)60043-0.

11. Feng J, Funk WD, Wang SS, et al. The RNA component of human telomerase. Science. 1995; 269:1236-41. DOI: $10.1126 /$ science. 7544491.

12. Kilian A, Bowtell DD, Abud HE, et al. Isolation of a candidate human telomerase catalytic subunit gene, which reveals complex splicing patterns in different cell types. Hum Mol Genet. 1997; 6:2011-9.

13. Gardano L, Holland L, Oulton R, et al. Native gel electrophoresis of human telomerase distinguishes active complexes with or without dyskerin. Nucleic Acids Res. 2012; 40(5):e36. DOI:10.1093/nar/gkr1243.

14. Collins K. Structure and function of telomerase. Curr Opin Cell Biol. 1996; 8:374-80. DOI: 10.1016/S09550674(96)80013-5.

15. Hiyama E, Tatsumoto N, Kodama T, et al. Telomerase activity in human intestine. Int J Oncol. 1996; 9(3): 453-8. DOI: 10.3892/ijo.9.3.453.

16. Zhang F, Huber O, Ménard L, et al. Pontin and reptin, two related ATPases with multiple roles in cancer. Cancer Res. 2008; 68(17):6873-6. DOI: 10.1158/00085472.CAN-08-0547.

17. Zhang F, Cheng D, Wang S, Zhu J. Human Specific Regulation of the Telomerase Reverse Transcriptase Gene. Genes (Basel). 2016; 7(7). pii: E30. DOI: 10.3390/genes 7070030 .

18. Yoshida K, Sugino T, Goodison S, et al. Detection of telomerase activity in exfoliated cancer cells in colonic luminal washings and its related clinical implications. Br J Cancer. 1997; (75) 548-553. DOI:10.1038/ bjc.1997.96.

19. Myung SJ, Yang SK, Chang HS, et al. Clinical usefulness of telomerase for the detection of colon cancer in ulcerative colitis patients. J Gastroenterol Hepatol. 2005; (20)1578-1583. DOI: 10.1111/j.14401746.2005.03877.x.

20. Meyerson M, Counter CM, Eaton EN, et al. hEST2, the putative human telomerase catalytic subunit gene, is up-regulated in tumor cells and during immortalization. Cell. 1997; 90(4):785-95. DOI: http://dx.doi. org/10.1016/S00928674(00)80538-3.

21. Frost M, Bobak JB, Gianani R, et al. Localization of telomerase hTERT protein and hTR in benign mucosa, dysplasia, and squamous cell carcinoma of the cervix. Am J Clin Pathol. 2000; 114(5): 726-34. DOI:10.1309/ XWFE-ARMN-HG2D-AJYV.

22. Yokoyama Y, Takahashi Y, Shinohara A, et al. Telomerase activity in the female reproductive tract and neoplasms. Gynecol Oncol. 1998; 68:145-9 DOI:10.1006/gyno.1997.4921.

23. Kyo S, Takakura M, Kohama T, et al. Telomerase activity in human endometrium Cancer Res. 1997; 57:610-4.

24. Yokoyama Y,Takahashi Y, Morishita S, et al. Telomerase activity in the human endometrium throughout the menstrual cycle. Mol Hum Reprod. 1998; 4:173-7. DOI: 10.1093/molehr/4.2.173.

25. Gorham H, Yoshida K, Sugino T, et al. Telomerase activity in human gynecological malignancies. J Clin Pathol. 1997; 50:501-4. DOI: 10.1136/jcp.50.6.501.

26. Brien TP, Kallakury BV, Lowry CV, et al. Telomerase activity in benign endometrium and endometrial carcinoma. Cancer Res. 1997; 57: 2760-64.

27. Nobre RJ, de Almeida LP, Martins TC. Complete genotyping of mucosal human papillomavirus using a 
restriction fragment length polymorphism analysis and an original typing algorithm. J Clin Virol. 2008; 42(1):13-21. DOI: 10.1016/j.jcv.2007.11.021.

28. Saleh S,LamAK, HoYH. Real-timePCR quantification of human telomerase reverse transcriptase (hTERT) in colorectal cancer. Pathology. 2008; 40(1):25-30. DOI: $10.1080 / 00313020701716425$.

29. Livak KJ, Schmittgen TD. Analysis of relative gene expression data using real-time quantitative PCR and the 2(-Delta Delta C(T)) Method. Methods. 2001; 25(4):402-8. DOI: 10.1006/meth.2001.1262.

30. Branca M, Giorgi C, Ciotti M, et al. Upregulation of telomerase (hTERT) is related to the grade of cervical intraepithelial neoplasia, but is not an independent predictor of high-risk human papillomavirus, virus persistence, or disease outcome in cervical cancer. Diagn Cytopathol. 2006; 34(11):739-48. DOI: 10.1002/dc.20554.

31. Hsu CG, Wang PH, Ko JL, et al. Concurrent high expression of human telomerase reverse transcriptase and human non metastatic clone 23 in high-grade squamous intraepithelial neoplasia and squamous cell carcinoma of uterine cervix. Int J Gynecol Cancer. 2007;17(4):851-7. DOI:10.1111/j.15251438.2007.00894.x.

32. Wang HY, Park S, Kim S, et al. Use of hTERT and HPV E6/E7 mRNA RT-qPCR TaqMan assays in combination for diagnosing high-grade cervical lesions and malignant tumors. Am J Clin Pathol. 2015; 143(3):344-51. DOI:10.1309/ AJCPF2XGZ2XIQYQX.

33. Saretzki G, Fischer H, Kaufmann IG, et al. Telomerase activity in cervical smears. Anal Cell Pathol. 2001; 23(1):39-43. DOI: 10.1155/2001/630972.

34. Reesink-Peters N, Helder MN, Wisman GB, et al. Detection of telomerase, its components, and human papillomavirus in cervical scrapings as a tool for triage in women with cervical dysplasia. J Clin Pathol. 2003; 56(1):31-5. DOI:10.1136/jcp.56.1.31.

35. Nagai N, Oshita T, Murakami J, et al. Semiquantitative analysis of telomerase activity in cervical cancer and precancerous lesions. Oncol Rep. 1999; 6(2):325-8. DOI:10.3892/or.6.2.325.

36. Reddy VG, Khanna N, Jain SK, et al. Telomerase-A molecular marker for cervical cancer screening. Int J Gynecol Cancer. 2001; 11(2):100-6. DOI: 10.1046/j.1525-1438.2001.00095.x.

37. Castro-Duque AF, Loango-Chamorro N, RuizHoyos BM, et al. Telomerase activity associated with progression of cervical lesions in a group of Colombian patients. Rev Bras Ginecol Obstet. 2015; 37(12):559-64. DOI: 10.1590/SO100720320150005462 .

38. Kyo S, Takakura M, Tanaka M, et al. Telomerase activity in cervical cancer is quantitatively distinct from that in its precursor lesions. Int J Cancer.
1998; 79(1):66-70. DOI: 10.1002/(SICI)10970215(19980220)79:1<66::AID-IJC13>3.0.CO;2-F.

39. Takakura M, Kyo S, Kanaya T, et al. Expression of human telomerase subunits and correlation with telomerase activity in cervical cancer. Cancer Res. 1998; 58(7):1558-61.

40. Ault KA, Allen HK, Phillips SL, et al. Telomerase activity as a potential diagnostic marker for triage of abnormal Pap smears. J Low Genit Tract Dis. 2005; 9(2):93. DOI: 10.1097/00128360-200504000-00005.

41. Kailash U, Soundararajan CC, Lakshmy R, et al. Telomerase activity as an adjunct to high-risk human papillomavirus types 16 and 18 and cytology screening in cervical cancer. Br J Cancer. 2006;95(9):1250-7. DOI:10.1038/sj.bjc.6603375.

42. Cong YS, Wright WE, Shay JW. Human telomerase and its regulation. Microbiol Mol Biol Rev. 2002;66(3):407-25. DOI: 10.1128/MMBR.66.3.407425.2002 .

43. Cao Y, Bryan TM, Reddel RR. Increased copy number of the TERT and TERC telomerase subunit genes in cancer cells. Cancer Sci. 2008; 99(6):10929. DOI: 10.1111/j.1349-7006.2008.00815.x.

44. Klingelhutz AJ, Foster SA, McDougall JK. Telomerase activation by the E6 gene product of human papillomavirus type 16. Nature. 1996; 380(6569):79-82. DOI:10.1038/380079a0.

45. Huang PS, Patrick DR, Edwards G, et al. Protein domains governing interactions between E2F, the retinoblastoma gene product, and human papillomavirus type $16 \mathrm{E} 7$ protein. Mol Cell Biol. 1993; 13(2):953-60. DOI: 10.1128/MCB.13.2.953.

46. Oh ST, Kyo S, Laimins LA. Telomerase activation by human papillomavirus type 16 E6 protein: induction of human telomerase reverse transcriptase expression through Myc and GC-rich Sp1 binding sites. J Virol. 2001; 75(12):5559-66. DOI:10.1128/ JVI.75.12.5559-5566.2001.

47. Cullen AP, Reid RI, Campion MI, et al. Analysis of the physical state of different human papillomavirus DNAs in intraepithelial and invasive cervical neoplasm. J Virol. 1991;65(2):606-12.

48. Doorbar J, Quint W, Banks L, et al. The biology and life-cycle of human papillomaviruses. Vaccine. 2012; 30:F55-70. DOI: 10.1016/j.vaccine.2012.06.083.

49. Wang SZ, Sun JH, Zhang W, et al. Telomerase activity in cervical intraepithelial neoplasia. Chin Med J (Engl). 2004; 117(2):202-6.

50. Snijders PJ, van Duin M, Walboomers JM, et al. Telomerase activity exclusively in cervical carcinomas and a subset of cervical intraepithelial neoplasia grade III lesions: strong association with elevated messenger RNA levels of its catalytic subunit and high-risk human papillomavirus DNA. Cancer Res. 1998; 58(17):3812-8. 


\title{
Резиме
}

\section{КОРЕЛАЦИЈА НА ЕКСПРЕСИЈАТА НА ТЕЛОМЕРАЗНИОТ ГЕН СО ЦЕРВИКАЛНИТЕ ЦИТОЛОШКИ АБНОРМАЛНОСТИ И ИНФЕКЦИЈАТА СО ХУМАНИОТ ПАПИЛОМА ВИРУС}

\author{
Вјоса А. Зејнулаху ${ }^{1}$, Валон А. Зејнуллху ${ }^{1}$, Славица Јосифовска², \\ Никола Вуковиќ ${ }^{2}$, Кирил Паковски ${ }^{2}$, Сашо Панов ${ }^{2}$ \\ ${ }^{1}$ Оддел за акушерство и гинекологија, Универзитетски клинички центар на Косово, Приштина, Косово \\ ${ }^{2}$ Одделение за молекуларна биологија и генетика, Институт за биологија, Природно-математички фа- \\ култет, Универзитет Св. Кирил и Методиј, Скопје, Република Македонија
}

Вовед: Теломеразната реверзна транскриптаза (ТЕРТ) е главна каталитичка субединица на ензимскиот комплекс теломераза. Теломеразната активност е регулирана на повеќе нивоа и поголем број студии индицираат дека зголемената експресија на генот за хуманата TERT (hTERT) на транскрипциско низво резултира со бесмртен клеточен фенотип, кој е поврзан со канцерот. Целта на оваа студија е да се определи корелацијата меѓу експресијата на генот hTERT и присуството на разни цервикални прекурзорни лезии, како и со цервикален канцер, кај пациенти со потврдена инфекција со хуманиот папиломавирус (HPV).

Материјали: Во оваа студија беа анализирани цервикални брисеви од 214 пациентки кај кои истовремено е земен примерок за Папаниколау (Pap) тест. Детекцијата и генотипизацијата на HPV беа извршени со полимеразна верижна реакција (PCR) со последователна рестрикциска анализа (RFLP). Генската експресија е определувана со квантитативна PCR во реално време (qRT-PCR) co користење на TaqMan-проби и е изразувана релативно во однос на референтниот ген.

Резултати: Експресиските нивоа на hTERT се сигнификантно зголемени кај цитолошките високи и ниски градуси, наспроти контролните примероци со нормален наод ( $<0,01)$. Зголемената експресија е поврзана со 6,31 пати повисок ризик од развој на ASC-US и 9,20 за развој на LSIL. Покрај Toa, најдена е статистички значајна корелација на HPV-инфекцијата со експресијата на генот hTERT кај лезиите со висок градус и кај цервикалниот карцином. Вредностите на релативната експресија на hTERT покажуваат специфичност од 98\% и сензитивност од 100 \% при идентификацијата на цервикалните лезии, особено на ACS-H, HSIL и на цервикалниот карцином.

Заклучок: Со оглед на тоа што експресијата на генот hTERT корелира со цитолошкиот градус на цервикалните лезии и со присуството на инфекција со HPV, може потенцијално да биде користена како дијагностички и прогностички маркер.

Клучни зборови: теломераза, генска експресија, цервикален канцер, цервикални прекурзорни лезии, хуман папилома вирус 